\title{
Characteristics and accumulation mechanism of tight sandstone gas reservoirs in the Upper Paleozoic, northern Ordos Basin, China
}

\author{
Liu Guangdi ${ }^{1}$, Sun Mingliang ${ }^{1}$, Zhao Zhongying ${ }^{1,2}$, Wang Xiaobo ${ }^{1,2}$ and Wu \\ Shenghe ${ }^{1}$ \\ ${ }^{1}$ State Key Laboratory of Petroleum Resource and Prospecting, China University of Petroleum, Beijing 102249, China \\ ${ }^{2}$ Research Institute of Petroleum Exploration \& Development, PetroChina, Beijing 100083, China \\ (C) China University of Petroleum (Beijing) and Springer-Verlag Berlin Heidelberg 2013
}

\begin{abstract}
The Ordos Basin is a significant petroliferous basin in the central part of China. The Carboniferous and Permian deposits of transitional and continental facies are the main gas-bearing layers in the north part of the basin. The Carboniferous and Permian natural gas reservoirs in the northern Ordos Basin are mainly tight sandstone reservoirs with low porosity and low permeability, developing lots of "sweet spots" with comparatively high porosity and permeability. The tight sandstones in the study area are gas-bearing, and the sweet spots are rich in gas. Sweet spots and tight sandstones are connected rather than being separated by an interface seal. Sweet spot sand bodies are vertically and horizontally overlapped, forming a large gas reservoir group. In fact, a reservoir formed by a single sweet spot sand body is an open gas accumulation. In the gentle dipping geological setting and with the source rocks directly beneath the tight reservoirs over a large area, the balance between gas charging into tight reservoirs from source rocks and gas loss from tight reservoirs through caprock is the key of gas accumulation in tight sandstones. Both the non-Darcy flow charging driven by source-reservoir excess pressure difference and the diffusion flow charging driven by source-reservoir gas concentration difference play an important role in gas accumulation. The results of mathematical modeling indicate that the gas accumulation cannot be formed by just one of the above mechanisms. The diffusion of gas from source rocks to reservoirs is a significant mechanism of tight sandstone gas accumulation.
\end{abstract}

Key words: Tight sandstone, gas accumulation, gas diffusion, Upper Paleozoic, Ordos Basin

\section{Introduction}

Tight sandstone gas plays an important role in natural gas resources and also will become a significant target for future exploration and development of natural gas. These gas reservoirs are tight, strongly heterogeneous, and the gas saturation changes a lot within the reservoir. Gas accumulation mechanisms, distribution of sweet spots, and many other aspects of this kind of gas reservoir are still unclear, which largely limit the exploration and development of tight sandstone gas. Chinese and foreign researchers have emphasized their studies on sealing mechanisms with regard to the accumulation of tight sandstone gas. They have proposed hydrodynamic sealing, relative permeability, lack of buoyancy and stratigraphic diagenesis sealing theories (Berry, 1959; Masters, 1979; Gies, 1981; Jones, 1980; Brown et al, 1982; Rahmani, 1984; Welte et al, 1984). Past studies of charging, migration and accumulation mechanisms

*Corresponding author. email: lgd@cup.edu.cn

Received July 29, 2013 of tight sandstone gas reservoirs were mainly on deep basin gas, and piston-like pushing migration and dynamic accumulation have been proposed (Gies, 1982; 1984; Brown et al, 1986; Berkenpas, 1991; Masters, 1984; McPeek, 1981; Shanley et al, 2004; Law and Dickinson, 1985). However, the Upper Paleozoic tight sandstone gas reservoirs in the northern Ordos Basin mainly have low porosity and low permeability with source-reservoir overlap contact over a large area, and the accumulation mechanism and conditions are obviously different from deep basin gas, which results in a significant difference in gas enrichment. Therefore, studies on the charging mechanisms and enrichment of the Upper Paleozoic tight sandstone gas in the northern Ordos Basin are theoretically and practically important for exploration and development of this kind of gas accumulation.

\section{Geological setting}

The Ordos Basin is located in the vast loess plateau and desert steppe region of central China, which is to the north of the Qinling Mountains, south of the Yin Mountains, east of the Helan Mountains and west of the Lüliang Mountains, with 
an area of $25 \times 10^{4} \mathrm{~km}^{2}$. The thickness of sedimentary rocks in the basin is $5,000-18,000 \mathrm{~m}$, and the basin is a large wide west-dipping monocline in structure with a regional gradient of $3-5 \mathrm{~m} / \mathrm{km}$ (Fig. 1).

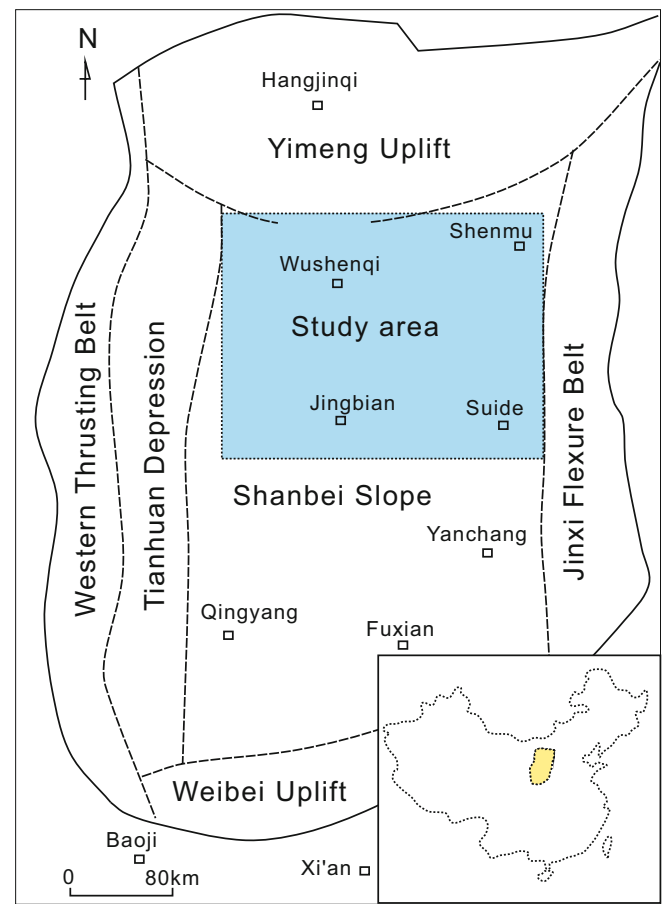

Fig. 1 Location of the Ordos Basin (Modified after Yang, 2002)
The Ordos Basin is a residual cratonic basin in the western end of the Paleozoic North China platform (Yang, 2002; He, 2003), and it has experienced five evolutionary stages, i.e. Middle-Late Proterozoic aulacogen, Early Paleozoic epeiric sea, Late Paleozoic coastal plain, Mesozoic inland basin and Cenozoic circumferential fault depression (Fig. 2).

The Upper Paleozoic in the basin are sediments of transitional and continental facies of the Carboniferous Benxi Formation and Taiyuan Formation, and the Permian Shanxi Formation, Lower Shihezi Formation, Upper Shihezi Formation and Shiqianfeng Formation. The coal-bearing strata of the Benxi, Taiyuan and Shanxi formations are the main source rocks, the fluvial-deltaic sandstones of the Shanxi and Lower Shihezi formations are the main reservoir rocks, and the thick lacustrine mudstones of the Upper Shihezi and Shiqianfeng formations serve as the regional seal rocks. The Sulige, Yulin, Daniudi and other huge gas fields have been found in the Upper Paleozoic of the northern Ordos Basin. Among them, the Sulige gas field is the largest gas field in China at present.

\section{The basic features of tight sandstone gas accumulation}

The Upper Paleozoic natural gas of the Ordos Basin mainly comes from coal strata of the Carboniferous Benxi Formation and Lower Permian Shanxi Formation, and is

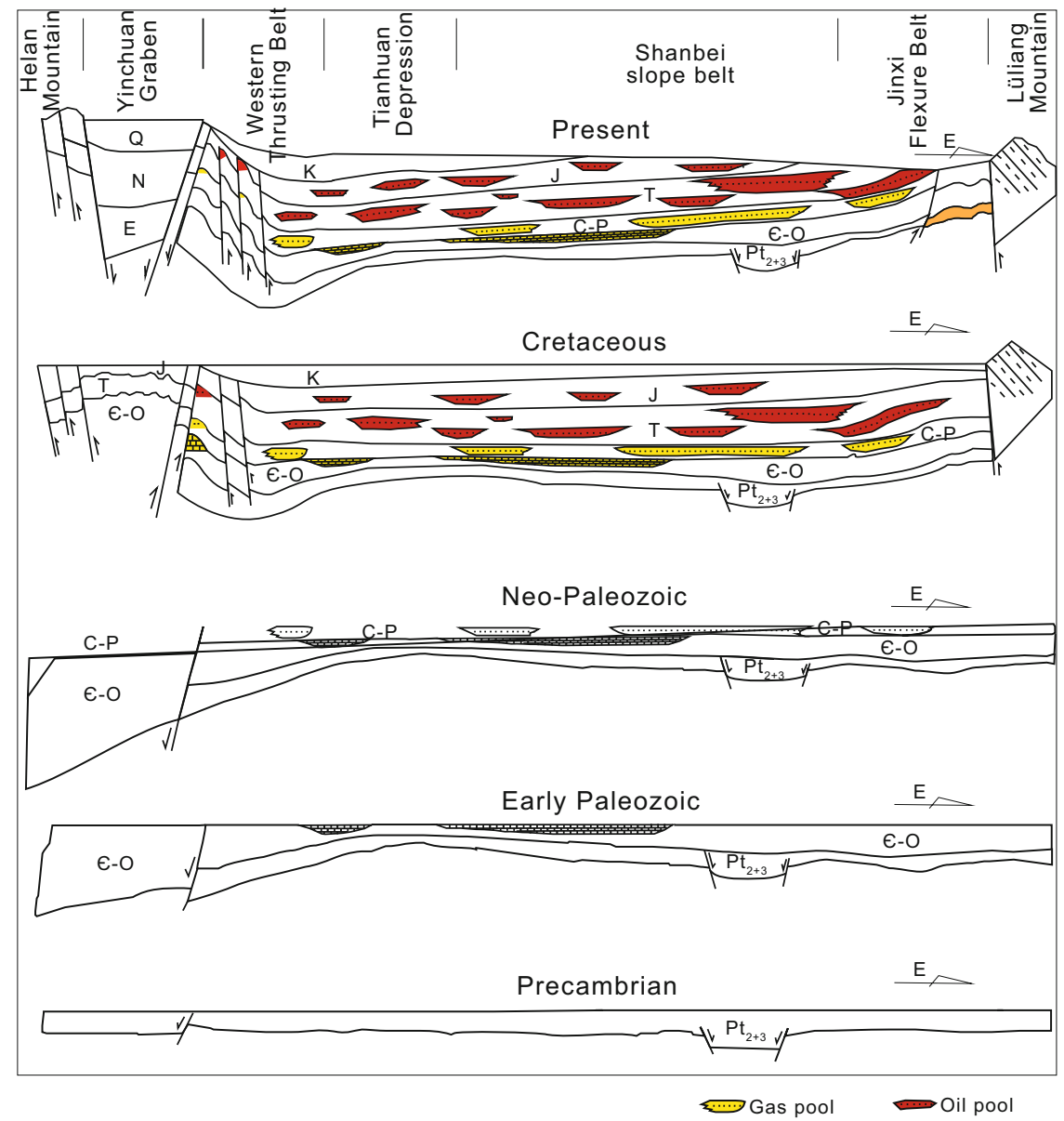

Fig. 2 Structure development of the Ordos Basin (Modified after Yang, 2002) 
mainly preserved in tight sandstones of the Permian Shanxi Formation and Lower Shihezi Formation, in which the fluvial-deltaic sandstones developed in the second member of the Shanxi Formation and the eighth member of the Lower Shihezi Formation are the main reservoir rocks and the Upper Shihezi Formation mudstones are the main cap rocks. The source rocks and reservoir rocks directly contact in a large area (Fig. 3). This source and reservoir combination pattern creates generally gas-bearing tight sandstones. The sweet spots have relatively high gas saturation and relatively high yield, but the widely distributed tight sandstones have low gas saturation and low natural gas yield, which is a characteristic of the Upper Paleozoic tight sandstone gas accumulation of the Ordos Basin.

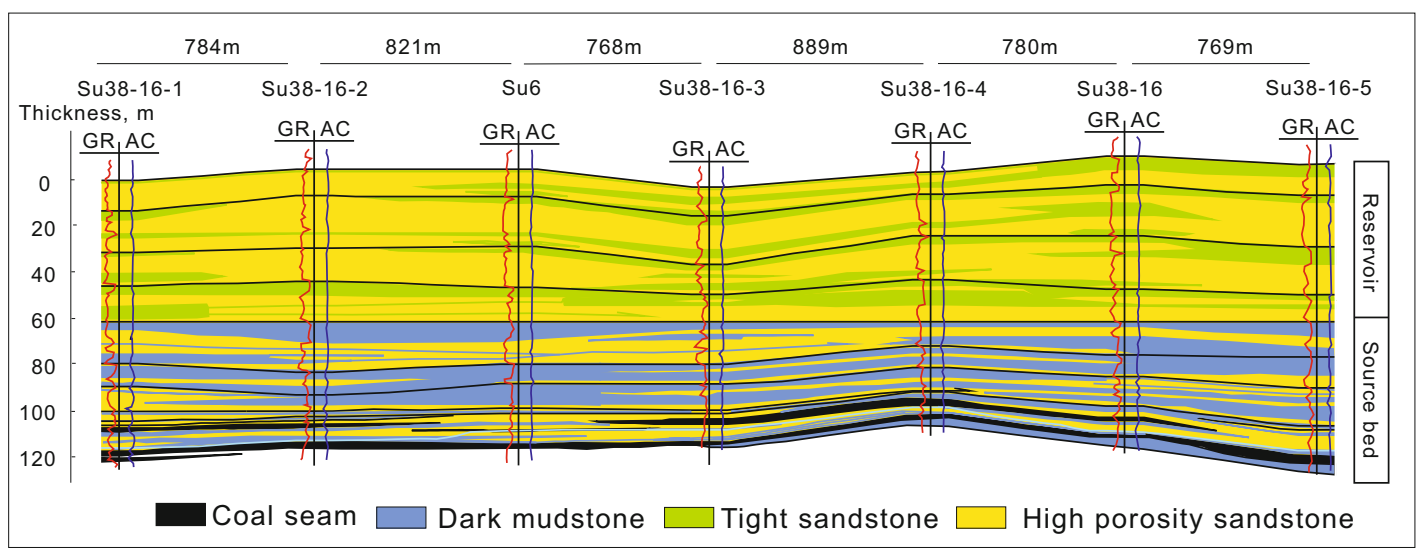

Fig. 3 Section of the Shanxi Formation-He8 in the Sulige Field

\subsection{Tight sandstone reservoir developing sweet spots}

According to the current classification of clastic rock reservoirs in China, reservoirs with porosity lower than $10 \%$ and permeability lower than $1 \times 10^{-3} \mu \mathrm{m}^{2}$ are categorized as low porosity and low permeability reservoir. Reservoirs with permeability lower than $0.1 \times 10^{-3} \mu \mathrm{m}^{2}$ are categorized as the lowest permeability reservoir. The statistics of porosity and permeability of the Upper Paleozoic gas reservoir in the northern Ordos Basin indicate that the reservoir is a typical low porosity and low permeability reservoir (Fig. 4) since its porosity is between $2 \%$ and $10 \%$, with a maximum of $18 \%$, and its permeability is between $0.01 \times 10^{-3} \mu^{2}$ and $0.5 \times 10^{-3}$ $\mu \mathrm{m}^{2}$. For the main gas producing reservoir, i.e., the sweet spot, the porosity is generally greater than $6 \%$ and the permeability is usually above $1 \times 10^{-3} \mu^{2}$, which means that sweet spots develop locally in the low porosity and low permeability background. Hence the first feature of the gas accumulation in the northern Ordos Basin is that the reservoirs are tight sandstones with low porosity and low permeability, but sweet spots have developed with relatively high porosity and permeability.
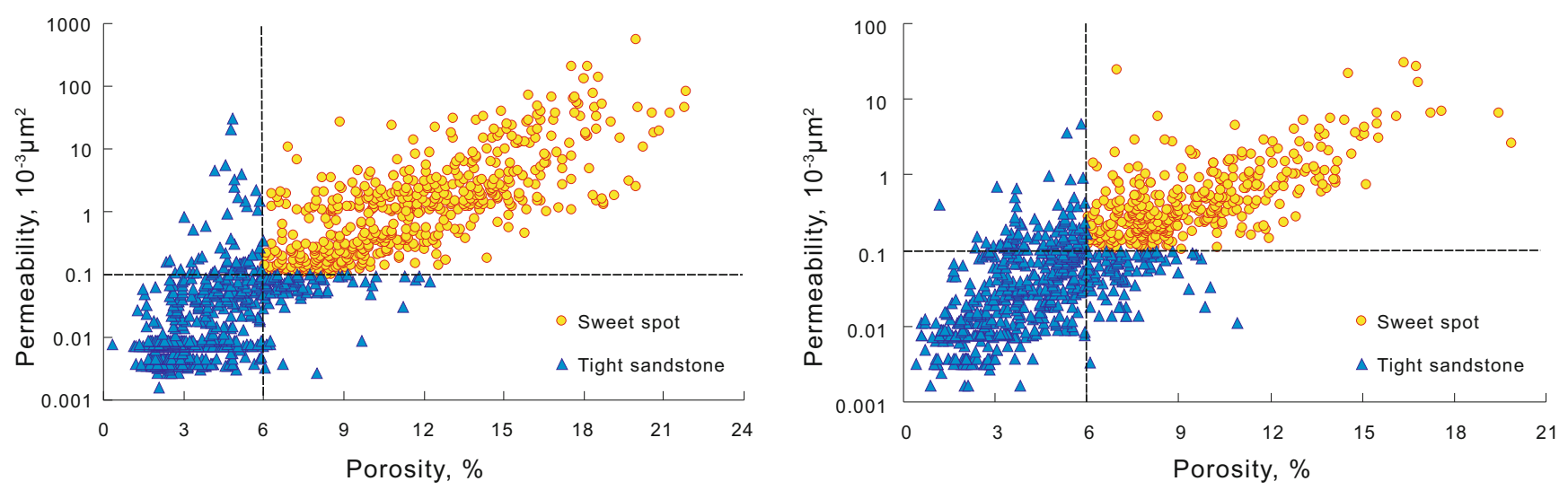

Fig. 4 Plot of porosity versus permeability of reservoir rocks in the He8 member (left) and Shan1 member (right) in the Sulige gas field

\subsection{Sweet spots vertically and laterally overlap, forming a widely distributed effective reservoir}

The main reservoir rocks in the Sulige gas field of the Ordos Basin are fluvial-deltaic deposits. The distribution range of a single channel sand body is limited and its continuity is poor with a lens-shape distribution. The general thickness of a single sand layer is $2-5 \mathrm{~m}$. An isolated single sweet spot formed in a single channel is shown in section (Fig. 5). In a single sand bed of the Sulige gas field, the sweet spots are scattered in the tight sandstones (Fig. 6(a)-6(f)).

After overlapping the sweet spots of each single layer, it is found that the originally isolated sweet spots become overlapped and connected (Fig. 6(g)). After the plane 
overlapping of each single layer, the area ratio of the sweet spots has increased from $15 \%-35 \%$ of each single layer to $96 \%$ of the whole bed. Because of the river migration, the sweet spots of different periods can be re-overlapped vertically and can also form a largely distributed and connected effective reservoir.

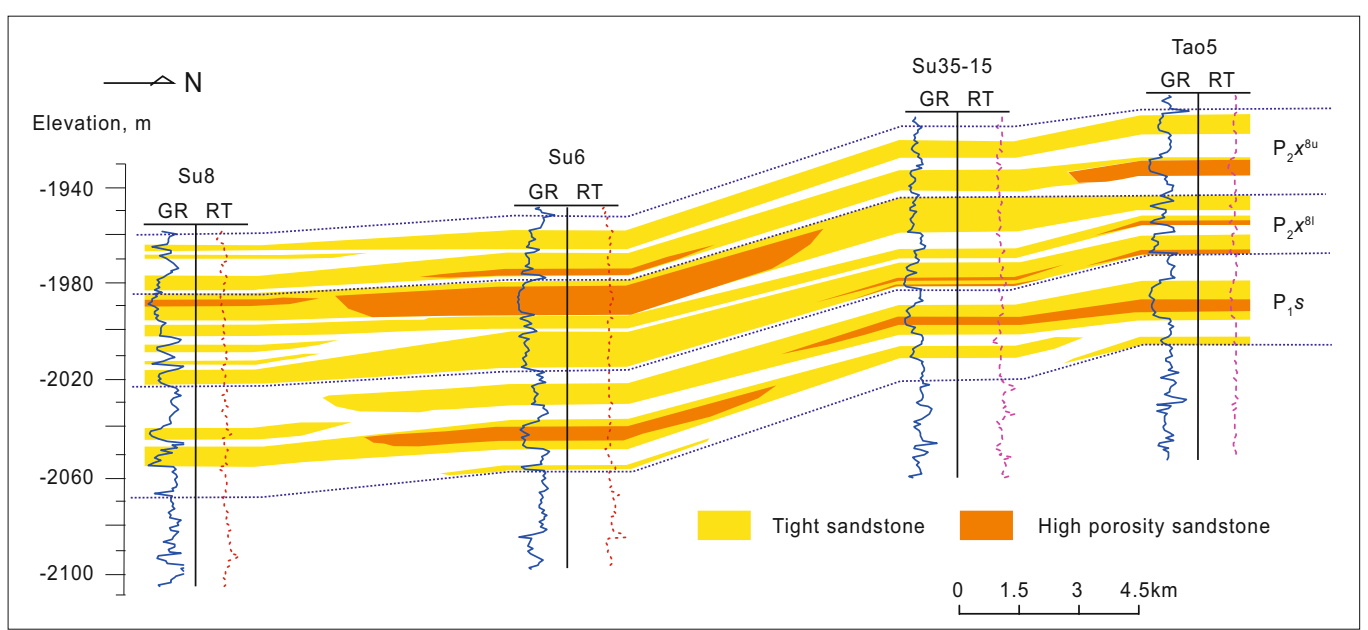

Fig. 5 Cross section of a sand body in the Su6 Block, Sulige gas field, Ordos Basin

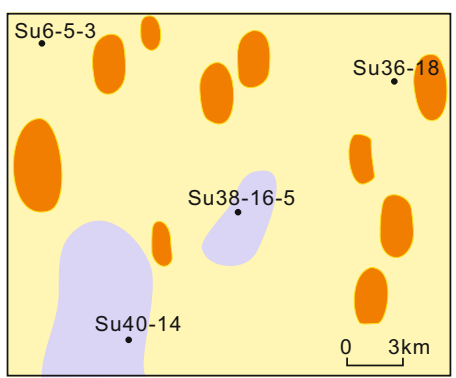

(a) $\mathrm{P}_{1} x^{\mathrm{U} 1}$

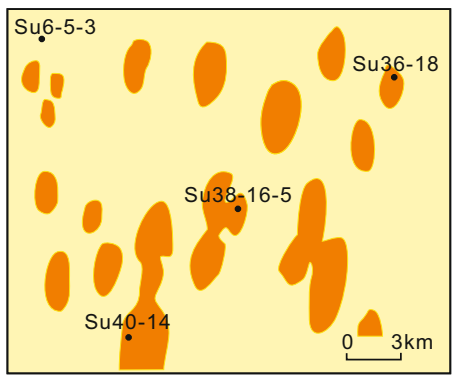

(d) $P_{1} x_{8}{ }^{L 2}$

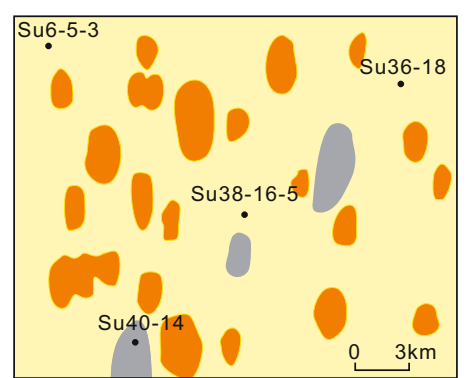

(b) $\mathrm{P}_{1} x_{8}{ }^{\mathrm{u}}$

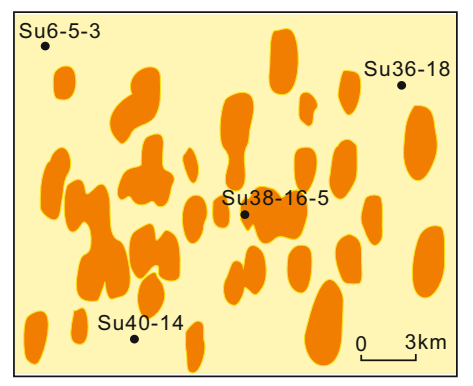

(e) $\mathrm{P}_{1} x_{8}{ }^{\mathrm{L} 3}$

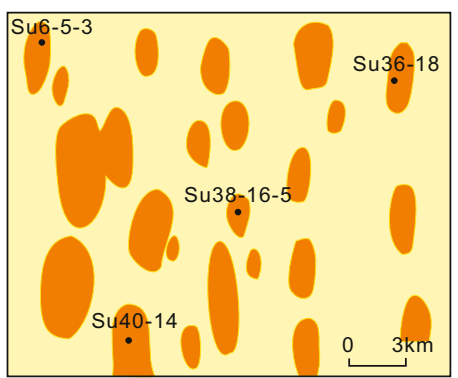

(c) $\mathrm{P}_{1} x_{8}^{\mathrm{L} 1}$

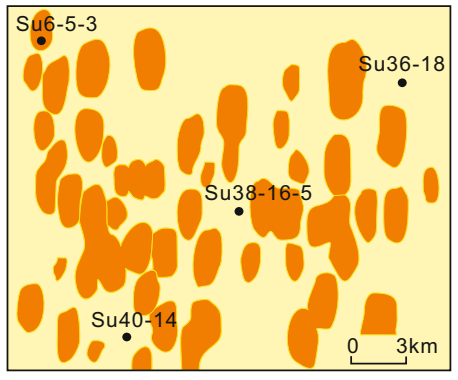

(f) $P_{1} x_{8}{ }^{L 4}$

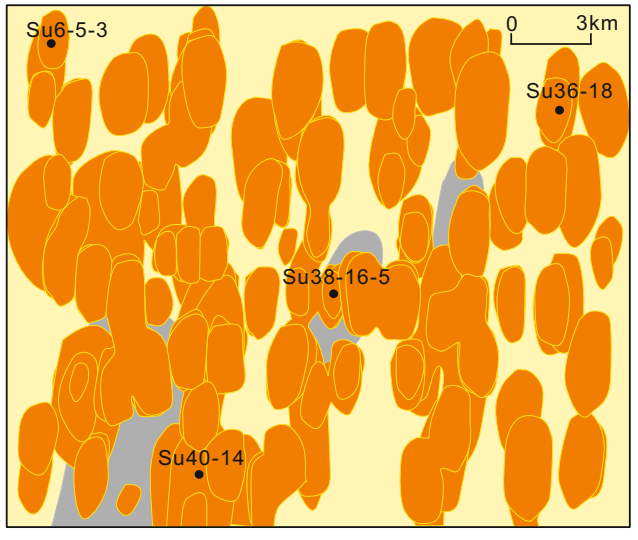

$\square$ Tight sandstone

(g) $P_{1} x_{8}$

Fig. 6 Sweet spot distribution of each layer of the He8 member in Well Su6 area, Sulige gas field 


\subsection{Tight sandstone is widely gas-bearing and sweet spots are rich in gas}

Statistics of gas saturation in the Sulige gas field indicate that in the Upper Paleozoic the widely distributed tight sandstones are all gas-bearing and the sweet spots have relatively high gas saturation.

Using logging data, the porosity, permeability and gas saturation of tight sandstones and sweet spots in 116 wells in the Sulige gas field have been interpreted and statistically analyzed. The result indicates that the gas saturation of sweet spots is higher than that of tight sandstones. The gas saturation of the sweet spot in the He 8 member is high, mainly ranging between $60 \%$ and $70 \%$, with an average of $59 \%$. The gas saturation of tight sandstones is low, mainly ranging between $40 \%$ and $50 \%$, with an average of $46 \%$ (Fig. 7, left). The average gas saturation of sweet spots in the Shan 1 member reservoir is $63 \%$ and the average gas saturation of tight sandstones is $46 \%$ (Fig. 7 , right).
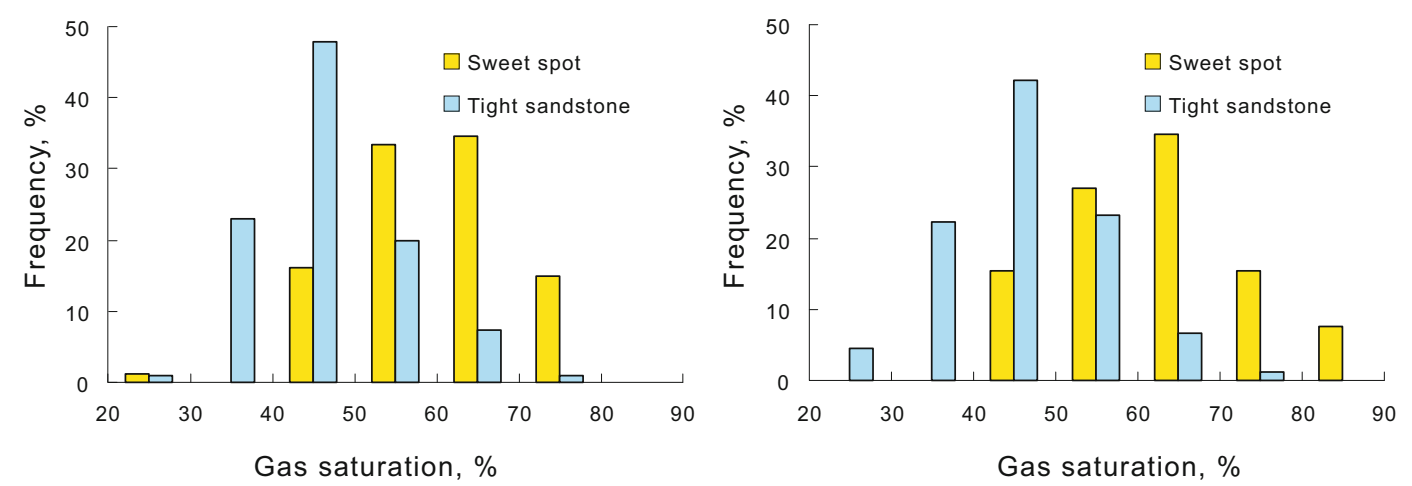

Fig. 7 Histogram of gas saturation of sweet spots and tight sandstones of the He8 member (left) and Shan1 member (right) in the Sulige gas field

\subsection{No sealing interface between sweet spots and tight sandstones, forming an open gas accumulation}

The analysis of sedimentary facies shows that the development of the Upper Paleozoic reservoirs in the Sulige gas field is mainly controlled by the sedimentary micro-facies. Sweet spots are mainly coarse-gained sandstone deposited in the channel bars of braided rivers, and the tight sandstone is mainly fine-grained sandstone deposited in braided channels. Sweet spots are isolated lenticularly and distributed in widespread tight sandstones. Sweet spots and peripheral tight sandstones have a sedimentary transitional relationship (Fig. 8).

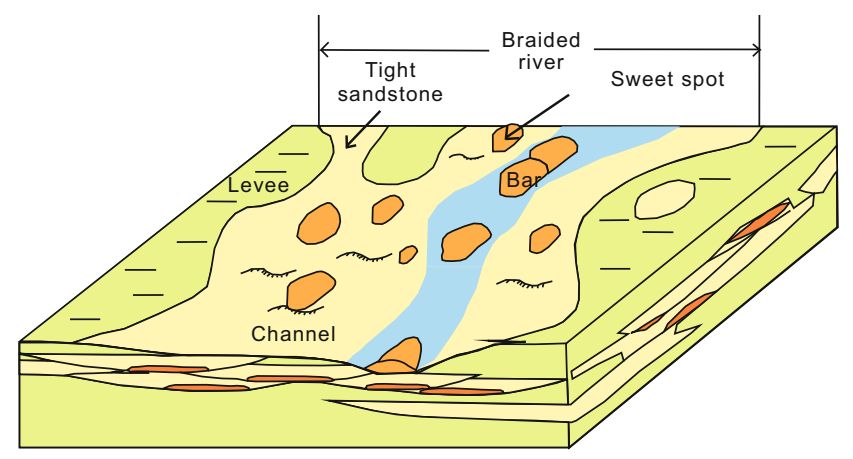

Fig. 8 Sedimentary model of the Upper Paleozoic sweet spots and tight sandstones, Sulige gas field

The calculation of the pressure system in the Ordos Basin also shows that there is no obvious sealing interface between the sweet spots and tight sandstones. A formation pressure test of the Upper Paleozoic in the Ordos Basin shows that the maximum underpressure of abnormal pressure formation is 11.4 MPa, which equals a gas column height of $1,363 \mathrm{~m}$ at gas density of $0.835 \mathrm{~kg} / \mathrm{m}^{3}$. At the formation dip $4^{\circ}$, this gas column height equals a maximum gas width of $19.5 \mathrm{~km}$ along the formation dip, which is basically consistent with the compound sand body width of the Upper Paleozoic delta. It illustrates that the tight sandstones and sweet spots are gasbearing overall. Therefore, it can be concluded that sweet spots and tight sandstones of the Ordos Basin are in the same pressure system and the gas can be exchanged between them. The boundary of the gas accumulation in a single sweet spot is open, forming an open gas accumulation.

\section{Accumulation mechanism of tight sandstone gas}

Since the Upper Paleozoic in the Ordos Basin has gentle dipping tight reservoirs and a large area of direct contact between source and reservoir, the accumulation mechanism and accumulation process of natural gas are obviously different from the accumulation of conventional natural gas reservoirs, and also quite different from the accumulation of North American deep basin gas. Previous studies reveal that the excess pressure difference between source and reservoir is the main driving force in the formation process of natural gas accumulation (Liu et al, 2005; 2008). Tight reservoirs have a high displacement pressure and the gas charging from source to reservoir needs higher excess pressure difference between source and reservoir. Meanwhile, the high displacement pressure increases the resistance to natural gas migration within the reservoir, which limits the free flow of natural gas in tight sandstones. Besides, the buoyancy effect is reduced because of the gentle dip of the reservoir, so lateral migration of natural gas within the tight reservoir is therefore limited in the scale and distance. 
In the conventional and deep basin gas reservoirs, diffusion charging of gas from source to reservoir was generally not considered as an effective process for natural gas accumulation. However, because of the large area of direct contact between source and reservoir in the Ordos Basin, gas diffusion from source to reservoir occurs at a large scale, hence, the amount of gas charged from source to reservoir by diffusion is greatly increased. If the gas amount charged by diffusion is more than the gas loss from the reservoir by diffusion, the diffusion charging will have a constructive effect on the accumulation of the tight sandstone gas.

\subsection{Non-Darcy flow charging driven by excess pressure difference between source and reservoir}

Sandstone samples with different permeabilities from the Sulige gas field have been selected for a simulation experiment of natural gas flow charging. The permeability of samples is (0.011-1.37) $\times 10^{-3} \mu^{2}$. The methane charging experiment is under the condition of $10 \mathrm{MPa} / \mathrm{m}, 8 \mathrm{MPa} / \mathrm{m}$ and $4 \mathrm{MPa} / \mathrm{m}$ pressure gradient, recording the charging time and quantity. By analyzing the experimental results, the correlation between starting pressure gradient and starting permeability under the experimental conditions can be generated after regression (Fig. 9). Fig. 9 shows that the minimum starting pressure gradient is $0.1 \mathrm{MPa} / \mathrm{cm}$ when the permeability is $0.1 \times 10^{-3} \mu \mathrm{m}^{2}$, and decreases to about 0.02 $\mathrm{MPa} / \mathrm{cm}$ when the permeability is $1 \times 10^{-3} \mu \mathrm{m}^{2}$. This result suggested that the gas flow charging from source rocks to tight sandstone reservoirs was a non-Darcy flow and the driving force was an excess pressure gradient between source and reservoir.

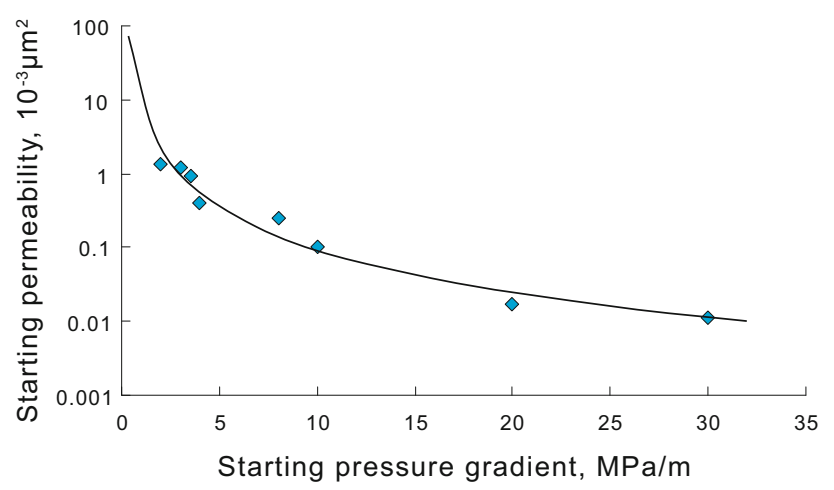

Fig. 9 Plot of starting pressure gradient versus starting permeability in simulation experiment

Previous studies showed that there was an abnormally high pressure in the Upper Paleozoic in the burial process of the Sulige gas field, and the pressure coefficient was more than 1.6. The pressure in the Upper Paleozoic decreased in the later uplift period due to a temperature decrease and gas diffusion (Yang et al, 2004; Yuan and Liu, 2005). At present the pressure is normal or low-amplitude under-pressure and the pressure coefficient is mostly less than 1. Based on mudstone compaction curves and fluid inclusion pressure calibration, the pressure evolution history of the source rocks and reservoirs in the Sulige gas field has been restored by using basin modeling. Studies on the excess pressure of source rocks of the Shan 2 member and reservoirs of He8 and Shan1 members reveal that there are characteristics of "high excess pressure, low excess pressure difference" between source rocks and reservoirs in the Sulige gas field. The excess pressure of source rocks and reservoirs is high, generally greater than $15 \mathrm{MPa}$, and the excess pressure difference between source rocks and reservoirs is low, generally less than $3 \mathrm{MPa}$ (Fig. 10). This result demonstrates that because the source rocks are close beneath the reservoir, this excess pressure difference will drive natural gas from source rocks to charge into the reservoir by non-Darcy flow.

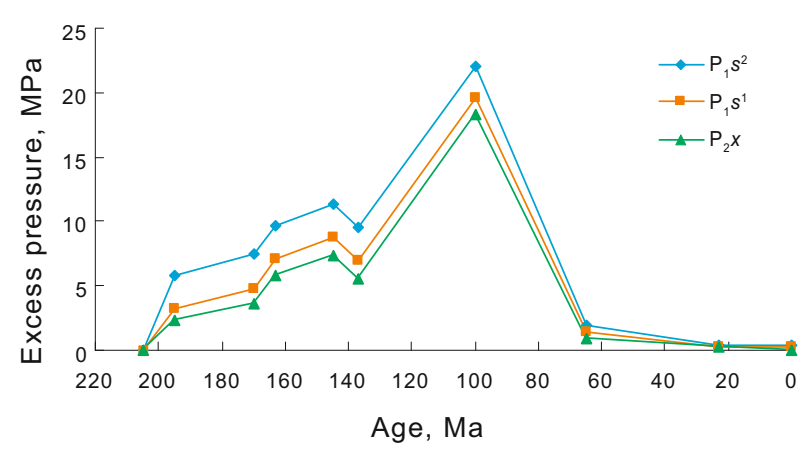

Fig. 10 Excess pressure evolution of source rocks and reservoir rocks in Well Su6, Sulige gas field

\subsection{Diffusion flow charging driven by source- reservoir hydrocarbon concentration difference}

The destructive effect of diffusion on natural gas accumulation has long been recognized by geologists. There are significant achievements in determination of the diffusion coefficient, diffusion modeling, calculation of diffusion amount and geochemical changes of natural gas caused by diffusion (Wang and Gao, 2005; Zhang and Krooss, 2001; Krooss and Leythaeuser, 1988; 1997; Krooss et al, 1992; Hao et al, 1991; Nelson and Simmons, 1995; Huang and Hao, 1996; Prinzhofer and Pernaton, 1997; Fang et al, 2001; Fu and Su, 2004; Wilson, 1996). However, there are few studies about the charging effect of natural gas except the early study of Leythaeuser et al (1982). Furthermore, there are even fewer studies on the effects of diffusion in natural gas accumulation.

Based on the study of the accumulation mechanism of the Sulige gas field and diffusion coefficient of natural gas in rocks (Liu et al, 2012), the geological and mathematical models of gas diffusion in different source-reservoir-cap assemblages (including diffusion charging and diffusion loss) have been established (Zhao, 2012). The charging, loss and accumulation of natural gas in tight reservoirs of the Upper Paleozoic in the Ordos Basin can be studied by a one-dimensional model based on the following facts, i.e. the lateral migration of natural gas in the reservoir can be neglected and gas mainly migrates vertically after being charged into the reservoir from source rocks due to the high displacement pressure and the gentle dipping of the Upper Paleozoic tight sandstone reservoirs. According to the natural gas migration and accumulation dynamic balance principle, the difference between the gas charged into and the gas lost 
from the tight reservoir is the gas accumulated in the tight reservoir.

Modeling of the gas accumulation of $\mathrm{Su} 7$ well in the northern Ordos Basin has been conducted using the above model. The results (Fig. 11) show that the natural gas charging intensity by non-Darcy flow is $5.9 \times 10^{8} \mathrm{~m}^{3} / \mathrm{km}^{2}$, the charging intensity by diffusion flow is $4.7 \times 10^{8} \mathrm{~m}^{3} / \mathrm{km}^{2}$, and the sum of these two is $10.6 \times 10^{8} \mathrm{~m}^{3} / \mathrm{km}^{2}$. The gas loss intensity of this well block is $7.2 \times 10^{8} \mathrm{~m}^{3} / \mathrm{km}^{2}$. Therefore the gas accumulation intensity (retention intensity) of the Upper Paleozoic reservoirs in this well block is $3.4 \times 10^{8} \mathrm{~m}^{3} / \mathrm{km}^{2}$. It can be concluded from the results that the amount of gas into the reservoir provided by a single mechanism of nonDarcy flow charging or diffusion flow charging is not enough to make up for the gas loss. Only by including both nonDarcy flow and diffusion does the amount of gas charged into the reservoir exceed the amount of gas loss, to form gas accumulation. Therefore, non-Darcy flow charging and diffusion flow charging both play an important role in the formation of tight sandstone gas reservoirs with wide sourcereservoir contact and gentle dipping such as the Ordos Basin. Diffusion is not only an important process in gas destruction but may also become an important mechanism of gas accumulation under certain conditions.

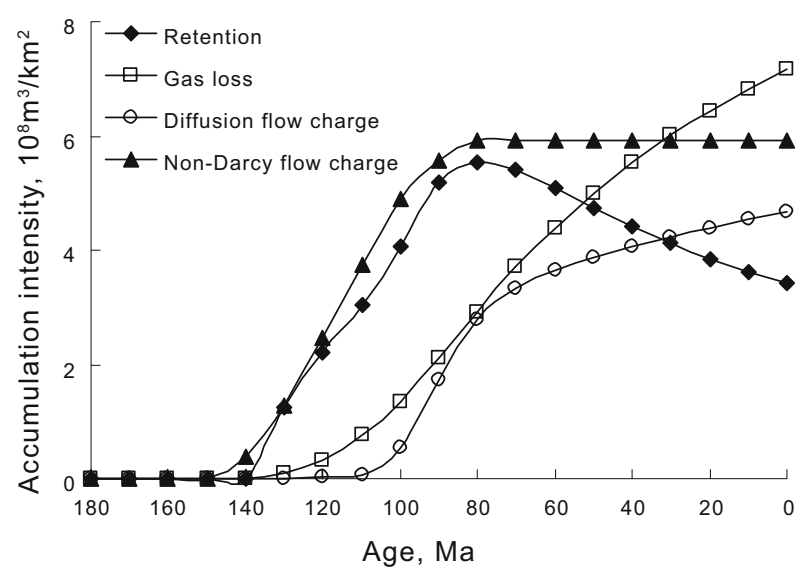

Fig. 11 Volume of gas expulsion (charging), accumulation, and diffusion of the Upper Paleozoic in Well Su7 of the Sulige gas field

\section{Conclusions}

1) The Upper Paleozoic gas fields in the northern Ordos Basin are open gas accumulations in sweet spots in a background of widely gas-bearing tight reservoirs. The Upper Paleozoic is mainly low porosity and low permeability, developing relatively high porosity and high permeability sweet spots. Tight reservoirs are gas-bearing, and the sweet spots are rich in gas. The sweet spots and tight sandstones are connected and there is no sealing interface between them. Sweet spot sand bodies overlap vertically and laterally, forming a widely distributed reservoir group. In fact, the reservoir formed by a single sweet spot sand body is an open gas accumulation.

2) Due to gentle dipping and widespread direct contact between source rocks and reservoirs of the Upper Paleozoic in the northern Ordos Basin, both the non-Darcy flow charging driven by source-reservoir excess pressure difference and the diffusion flow charging driven by sourcereservoir gas concentration difference play an important role in gas accumulation. The diffusion of gas from source rocks to reservoirs is a significant mechanism for gas accumulation in tight sandstone reservoirs.

\section{Acknowledgements}

This study was supported by the National Basic Research Program of China (No. 2007CB209503) and National Natural Science Foundation of China (No. 41102086).

\section{References}

Berkenpas P G. The Milk River shallow gas pool: Role of the updip water trap and connate water in gas production from the pool. SPE Annual Technical Conference and Exhibition. USA. 1991

Berry F A F. Hydrodynamics and geochemistry of the Jurassic and Cretaceous systems in the San Juan Basin, northwestern New Mexico and southwestern Colorado. Dissertation. Stanford California: Stanford University. 1959

Brown C A, Crafton J W and Golson J G. The Niobrara gas play: Exploration and development of a low-pressure, low-permeability gas reservoir. Journal of Petroleum Technology. 1982. 34(12): 28632870

Brown C A, Smagala T M and Haefele G R. Southern Piceance Basin model-Cozzette, Corcoran, and Rollins Sandstones. Geology of Tight Gas Reservoirs. AAPG Studies in Geology. 1986. 24: 207-220

Fang D Q, Song Y and Xia X Y. Natural gas diffusion model and diffusion computation in well Cai25 Bashan Group oil and gas reservoir. Science in China Series D: Earth Sciences. 2001. 44(3): 213-220

$\mathrm{Fu} \mathrm{G}$ and $\mathrm{Su}$ Y P. Geological factors controlling gas diffusion loss in strata section. Natural Gas Geoscience. 2004. 15(1): 58-61 (in Chinese)

Gies R M. Lateral trapping mechanism in the deep basin gas trap, western Canada. AAPG Bulletin. 1981. 65(5): 930

Gies R M. Basic physical principles of conventional and deep basin gas entrapment. AAPG Bulletin. 1982. 66: 572

Gies R M. Case history for a major Alberta deep basin gas trap: The Cadomin Formation. Tulsa: AAPG. 1984

Hao S S, Huang Z L and Gao Y B. A study of the diffusion of light hydrocarbon and the dynamic equilibrium principle in the migration and accumulation of natural gas. Acta Petrolei Sinica. 1991. 12(3): 17-24 (in Chinese)

He Z X. Basin Development and Hydrocarbon Exploration in the Ordos Basin. Beijing: Petroleum Industry Press. 2003. 1-44 (in Chinese)

Huang Z L and Hao S S. Study on sealing of gas concentration and diffusion in overlying gas reservoirs. Acta Petrolei Sinica. 1996. 17(4): 36-41 (in Chinese)

Jones R M P. Basinal isostatic adjustment faults and their petroleum significance. Bulletin of Canadian Petroleum Geology. 1980. 28(2): 211-251

Krooss B M and Leythaeuser D. Diffusion of methane and ethane through the reservoir cap rock: Implications for the timing and duration of catagenesis: Discussion. AAPG Bulletin. 1997. 81(1): 155-161

Krooss B M and Leythaeuser D. Experimental measurements of the diffusion parameters of light hydrocarbons in water-saturated sedimentary rocks-II. Results and geochemical significance. Organic Geochemistry. 1988. 12(2): 91-108

Krooss B M, Leythaeuser D and Schaefer R G. The quantification of diffusive hydrocarbon losses through cap rocks of natural gas reservoirs - a reevaluation. AAPG Bulletin. 1992. 76(3): 403-406 
Law B E and Dickinson W W. Conceptual model for origin of abnormally pressured gas accumulations in low-permeability reservoirs. AAPG Bulletin. 1985. 69(8): 1295-1304

Leythaeuser D, Schaefer R G and Yukler A. Role of diffusion in primary migration of hydrocarbons. AAPG Bulletin. 1982. 66(4): 408-429

Liu G D, Li J, Li J M, et al. The controls and the assessment method for the effectiveness of natural gas migration and accumulation process. Natural Gas Geoscience. 2005. 16(1): 1-6 (in Chinese)

Liu G D, Sun M L, Lü Y F, et al. The effectiveness assessment of gas accumulation processes in Kuqa Depression, Tarim Basin, Northwest China. Science in China Series D: Earth Sciences. 2008. 51(s2): 117125

Liu G D, Zhao Z Y, Sun M L, et al. New insights into natural gas diffusion coefficient in rocks. Petroleum Exploration and Development. 2012. 39(5): 559-565 (in Chinese)

Masters J A. Deep basin gas trap, western Canada. AAPG Bulletin. 1979. 63(2): 152-181

Masters J A. Lower Cretaceous oil and gas in western Canada. Tulsa: AAPG. 1984

McPeek L A. Eastern Green River basin: A developing giant gas supply from deep, overpressured Upper Cretaceous sandstones. AAPG Bulletin. 1981. 65(6): 1078-1098

Nelson J S and Simmons E C. Diffusion of methane and ethane through the reservoir cap rock: implications for the timing and duration of catagenesis. AAPG Bulletin. 1995. 79(1): 1064-1074

Prinzhofer A and Pernaton E. Isotopically light methane in natural gas: Bacterial imprint or diffusive fractionation? Chemical Geology. 1997. 142(3-4): 193-200

Rahmani R A. Facies control of gas trapping, Lower Cretaceous Falher A cycle, Elmworth area, northwestern Alberta. Tulsa: AAPG. 1984

Shanley K W, Cluff R M and Robinson J W. Factors controlling prolific gas production from low-permeability sandstone reservoirs: Implications for resource assessment, prospect development, and risk analysis. AAPG Bulletin. 2004. 88(8): 1083-1121

Wang W G and Gao N. Estimation of loss of gas diffusion from source rock in Binbei region. Journal of Daqing Petroleum Institute. 2005. 29(4): 1-3 (in Chinese)

Welte D H, Schaefer R G, Stoessinger W, et al. Gas generation and migration in the deep basin of western Canada. In: Elmworth (ed.), Case Study of a Deep Basin Gas Field. AAPG. 1984. 35-47

Wilson H H. Diffusion of methane and ethane through the reservoir cap rock: Implications for the timing and duration of catagenesis: Discussion. AAPG Bulletin. 1996. 80(9): 1483-1485

Yang H, Ji H, Li Z H, et al. Characteristics of underpressured gas pool in Upper Paleozoic Shiqianfeng Formation of eastern Ordos Basin. Earth Science-Journal of China University of Geosciences. 2004. 29(4): 413-419 (in Chinese)

Yang J J. Basin Structure Development and Distribution of Hydrocarbon in Ordos Basin. Beijing: Petroleum Industry Press. 2002. 8-22 (in Chinese)

Yuan J H and Liu G D. Distribution characteristics and formation process of Upper Paleozoic abnormally low pressure zones in Ordos Basin. Oil \& Gas Geology. 2005. 26(6): $792-799$ (in Chinese)

Zhang T W and Krooss B M. Experimental investigation on the carbon isotope fractionation of methane during gas migration by diffusion through sedimentary rocks at elevated temperature and pressure. Geochimica et Cosmochimica Acta. 2001. 65(16): 2723-2742

Zhao Z Y. Natural gas accumulation mechanism in low porosity and permeability sandstones: A case study of the Sulige gas field. Ph.D. Thesis. Beijing: China University of Petroleum. 2012. 77-84 (in Chinese)

(Edited by Hao Jie) 